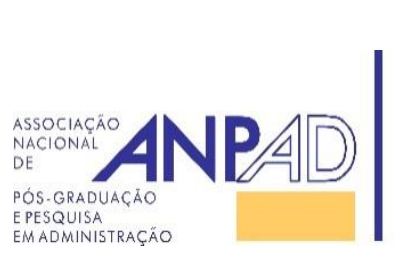

Available online at

http://www.anpad.org.br/bar

BAR, Rio de Janeiro, v. 13, n. 4, art. 5, e160057, Oct./Dec. 2016

http://dx.doi.org/10.1590/1807-7692bar2016160057

(c) BY

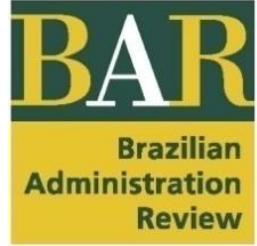

\title{
Network Effects on Radical Innovation and Financial Performance: An Open-mindedness Approach
}

Marcelo Gattermann Perin 1 Cláudio Hoffmann Sampaio ${ }^{1}$ Daniel Jiménez-Jiménez ${ }^{2}$ Juan Garcia Cegarra-Navarro ${ }^{3}$

Pontifícia Universidade Católica do Rio Grande do Sul ${ }^{1}$ Universidad de Murcia $^{2}$ Universidad Politecnica de Cartagena ${ }^{3}$

Received 9 June 2016; received in revised form in 24 November 2016 (this paper has been with the authors for two revisions); accepted in 25 November 2016; published online 14 December 2016. Editor's note. Valter Afonso Vieira served as Associate Editor for this article. 


\begin{abstract}
This study examines how companies can achieve high performance through certain organizational behaviors (open-mindedness and social networks) and innovation. The impact of open-mindedness in defiance of basic assumptions and processes could motivate the use of internal and external networks. These social networks are the cornerstone for the creation of knowledge and the construction of radical innovations, which in turn trigger the transformation new knowledge into organizational performance. We use structural equation modelling (SEM) to test our research model and hypotheses in a sample of 324 companies from the Brazilian industrial sector. Data were collected by a regular mail survey. The study brings a proper understanding that radical innovations play a crucial role for organizational performance in emerging economies. Results also show that open-mindedness is associated with both internal networks and external social networks. In addition, the external social network mediates the effects of open-mindedness on the internal social network. Finally, external social networks have an indirect influence on radical innovations, through internal social networks, and a direct effect on organizational performance.
\end{abstract}

Key words: open-mindedness; social networks; radical innovation; financial performance. 


\section{Introduction}

Perhaps the most objective pursued by most companies is to try to be competitive in the markets in which it operates. The idea, though attractive, is often a tortuous path in which companies must face different changes from political, economic, social and technological changes that affect the ways of creating value. Different strategies are adopted by companies to improve their results, innovation being a promising way to create value (Slater, Mohr, \& Sengupta, 2014).

One idea that is becoming evident in recent years is the need to seek models of generation of open innovation (Chesbrough, 2003; Dittrich \& Duysters, 2007; Hung \& Chou, 2013). The advantages of acquiring knowledge from different sources, both internal and external, allow companies to access a greater variety of techniques, research and knowledge that would be able to develop the company individually. This knowledge facilitates the creation of new knowledge that can be applied to development of innovations and, ultimately, to obtain greater business results (Kostopoulos, Papalexandris, Papachroni, \& Ioannou, 2011).

No wonder that companies are favoring collaboration with outside companies as a mechanism to promote their innovative capabilities and increase their competitive advantage (Pérez-Luño, CabelloMedina, Carmona-Lavado, \& Cuevas-Rodríguez, 2011). Thus, innovation and company success are linked through networks and relationships (Story, O’Malley, \& Hart, 2011), especially in an uncertain environment (M.-C. Wang \& Fang, 2012). This is especially truth when companies have to face difficulties to codify knowledge and intensive skills through processes of collaborative information sharing (Powell, 1990). Thus, social networks become the locus of innovation rather than companies that comprise the network in isolation (Powell, Koput, \& Smith-Doerr, 1996).

The benefits derived from networks constitute the definition for the organization social capital (Coleman, 1988; Houghton, Smith, \& Hood, 2009). By social capital we mean the "goodwill generated by the network of social relations" (Yang, Alejandro, \& Boles, 2011, p. 160), derived from the interaction between an organization and its internal and external agents (Bowey \& Easton, 2007).

Previous literature has underline that social networks play an important role for organizations and are a clear determinant of organizational performance (Stam, Arzlanian, \& Elfring, 2014). Those networks can make a critical opportunity for companies institutionalizing cooperation, sharing information and assuring results (Larson, 1992). They can also create value in alliances by enhancing coordination among companies participating in an alliance (Gulati, Nohria, \& Zaheer, 2000). Thus, the interactions between the business organization and the others firms contribute to financial performance (Håkansson, Ford, Gadde, Snehota, \& Waluszewski, 2009).

Researchers have also established the connections between organizational learning and innovation development (Chang \& Cho, 2008; Lynn, Reilly, \& Akgün, 2000; Madhavan \& Grover, 1998). In this way, social networks, as main sources of new knowledge, should be related to organizational innovation. They use the organization's internal experience, expertise, and processes to interpret the meaning of the external knowledge and to exploit it to generate innovations (Yangmin Kim \& Cannella, 2008). Pittaway, Robertson, Munir, Denyer and Neely (2004) have pointed a gap in the literature concerning to the relationship between networking and different types of innovation. In this sense, Cuevas-Rodríguez, Cabello-Medina and Carmona-Lavado (2014) had stated that more research should be done to point which organizational factors contribute to the impact of internal and external social network on radical innovation.

However, the emphasis on radical or breakthrough innovations demands a major intensity in the process of learning and the uses of different sources of knowledge to generate radical innovations (Slater et al., 2014). This suggests a disruption of the knowledge, practices and current relationships between the different agents with the target of generating really new and different products (Karim \& Kaul, 2015). Despite its importance, however, studies focusing on the determinants of radical innovation are 
still scarce. The radicalness of product innovations has received relatively less attention from researchers.

In this paper, besides exploring the influence of social network on radical innovation, we have focused on a key factor for the use of these networks and the generation of innovations: the openmindedness. The organizational receptiveness to new ideas is fundamental in business situations where the competitive intensity and market turbulence are high. Companies need new tools to distance themselves from their traditional routines in the search for new ideas and mechanisms to adapt to the environment (Slater et al., 2014). Open-mindedness had been theoretically related to social networks in the previous literature (Dombrowski et al., 2007; Hernández-Mogollon, Cepeda-Carrión, CegarraNavarro, \& Leal-Millán, 2010), but not empirically tested up to now. This relationship is crucial since generation of new ideas always starts from an open-mindedness that allows the company to be receptive to new trends and ideas that arise anywhere (Baker \& Sinkula, 1999). This means that the company will be sensible to consider different perspectives that arise from the contact with individuals or companies in their environment.

Furthermore, most of the proposed constructs were studied in development countries. However, it is important to study these relationships in other contexts, such as emerging economies, to understand its implications in other competitive conditions and technological turbulence (Sheth, 2011), where the existence of an external social network and radical innovation might produce different results (Kropp, Lindsay, \& Shoham, 2006). This idea is recognized by Burgess and Steenkamp (2006), who have pointed out the need to undertake more research in emerging markets, since the current body of studies does not offer a precise framework to explain firms' operation in those markets.

In summary, this study addresses the following two questions: Does the development of openmindedness in emerging markets trigger the creation and enhancement of social networks? Does the enhancement of social networks result in radical innovations and better performances?

The article is structured to understand these relationships and meet the next objectives. First, a literature review of the most important concepts and relationships is made. The influence of radical innovation in financial performance, the influence of the open-mindedness in the internal and external social networks and the influence of both social networks on radical innovation and financial performance is analyzed. The subsequent section describes the method used to test the hypotheses. The empirical data used for this investigation come from Brazilian firms and the results of the analysis are then presented. Finally, conclusions are presented together with suggestions for future research and then, a discussion of the limitations faced during the study.

\section{Conceptual Framework}

\section{The importance of radical innovations}

Traditionally it is considered that in a competitive and technological uncertainty environments companies cannot ignore strategies that allow them to adapt their businesses and develop new skills that enable them to achieve competitive advantages in this new context. Innovation is one of those tracks that allows to develop new products or services that compete and open possibilities for long-term livelihood. The Resource-Based View of the company (Wernerfelt, 1984) argues that a firm is a bundle of resources and capabilities. The main task of the company is to maximize its value through an optimal exploitation of its resources and capabilities, while developing the basis for future company resources (Grant, 1996). In this sense, the focus of the Resource-Based View constitutes an essential framework to study innovation because these resources and capabilities need to be managed successfully to develop innovation and generate competitiveness. Under this perspective, the introduction of new products also requires a set of processes to coordinate, improve, and reconfigure critical resources and capabilities. 
It should be noted, however, that the most noteworthy intangible resource is knowledge. As Grant (1996) argues, competitive firms exist because they better integrate and apply specialized knowledge than do their competitors. In doing so, organizational learning becomes a source of competitive advantage and heterogeneity for businesses due to the different capacities that companies must create to generate new knowledge (Easterby-Smith, Crossan, \& Nicolini, 2000; Lei, Slocum, \& Pitts, 1999). These capacities bring innovation in the company to incorporate the same new knowledge that can be used to develop a set of skills that can be adapted to the environment in which it moves (Kogut \& Zander, 1992; Lei, Hitt, \& Bettis, 1996; Leonard-Barton, 1992).

The literature focused on innovation proposes the distinction between innovations of incremental and radical type (García \& Calantone, 2002), although not always these two types of innovations are well discriminated (Slater et al., 2014), since differences in the terminology used and the large number of definitions create confusion (Story, Daniels, Zolkiewski, \& Dainty, 2014). At first, incremental innovation are minor changes and modifications to existing products (Ritala \& Sainio, 2014). Such innovations will target customers and current markets where the company competes (Lin, McDonough, Lin, \& Lin, 2013). Instead, radical product innovations incorporate substantially different technology that have existing products, and meet new customer needs (Xin, Yeung, \& Cheng, 2009). This requires the creation of new knowledge to facilitate the creation of substantially new products (Benner \& Tushman, 2003). Knowledge will allow to create different features that can be observed in existing products and markets (Sadovnikova, Pujari, \& Mikhailitchenko, 2016; Sheng \& Chien, 2016). It is not surprising that the literature indicates that a balance between the two types of innovation to achieve competitive advantages in the short and long term is required (Forés \& Camisón, 2016). However, comparatively less attention has been paid to radical innovation than other forms of innovation (Story et al., 2014).

Radical innovations involve creation of new markets (Rubera \& Kirca, 2012) or making deeper changes that destroy existing positions on the market today (Aboulnasr, Narasimhan, Blair, \& Chandy, 2008) and make obsolete current products (Beck, Lopes-Bento, \& Schenker-Wicki, 2016). However, the result of radical innovation is uncertain to assume greater levels of risk (Chandy \& Tellis, 1998) and harder to put into practice (Sorescu, Chandy, \& Prabhu, 2003). In addition, often companies do not recover the investment made in radical innovations, compared to incremental. However, the literature often considers them better to improve the long-term competitive advantage by providing improvements in customer value created, increased revenue or cost reduction (Woodside \& Biemans, 2005). Conversely, a firm's inability to develop radical innovations may compromise its longevity (Datta \& Jessup, 2013). Radical innovations enable organizations to achieve sustainable competitive advantages in the long term by generating economic rents (Song, Droge, Hanvanich, \& Calantone, 2005). These innovations offer greater customer benefits, cost reductions, or capabilities to create new businesses, any of which should lead to higher organizational performance (Slater et al., 2014). Moreover, radical product innovations facilitate customer loyalty and faster market penetration while reducing costs, volatility and vulnerability of cash flows (Boso et al., 2016). Despite some inconsistencies in the research findings, Bayus, Erickson, and Jacobson (2003) observe that the more innovative products are the greater acceptance in markets. These findings reinforce the idea that the radicalism of new products increases the success of innovation and provides competitive advantages for companies (Xin et al., 2009). Hence, the study proposes the following hypothesis:

$\mathbf{H}_{1}$ : Radical innovation positively impacts financial performance.

\section{Openness capability}

The development of innovations that facilitate creation of profitability for the company is based on application of new knowledge. According to the literature on organizational learning, a key source of knowledge is in the company internal or external social networks (Houghton et al., 2009). Internal networks may facilitate team working, transfer of knowledge from different departments and coordination of different functions (Yang et al., 2011). Consequently, these internal networks may allow integration of departmental work and can facilitate knowledge generation under the idea that "who you 
know affects what you know" (Nahapiet \& Ghoshal, 1998, p. 252). On the other hand, a firm's external network enables the company to gain resources from its environment and find new opportunities (Story et al., 2011). For instance, external networks can provide information about the customers' expertise that could be used for improving products (Youngok Kim \& Liu, 2015).

Network perspectives are based on the idea that economic actions determine the social context in which they are embedded and that actions can be explained by the position of the actors in social networks (Gulati, 1998). The literature on external networks has highlighted the advantages of cooperation with other entities in which the basic principle of these lies in the reciprocity between organizations who participate in the network (Powell, 1990). This exchange of information between network organizations enables them to acquire new information and generating organizational learning (Powell \& Brantley, 1992). Therefore, social networks become sources of innovations' generation (Podolny \& Page, 1998). Social networking can also be seen as an opportunity to learn. For instance, by using social networking websites users could improve their efficiency and coordination (SanchezCasado, Cegarra Navarro, Wensley, \& Tomaseti-Solano, 2016).

However, the possibilities offered by social networks will be determined by the attitude and ability of workers of the company. If relations are perceived as value, productive and satisfying, the employee will be more inclined to their interaction in them (Coleman, 1988). Moreover, inertia leads to individuals follow the same routines and outdated mental models, which prevent organizations to take advantage of new knowledge (Sinkula, 2002). Nevertheless, radical innovation requires environments that drive creativity and develop ideas, questioning established ideas, interchanging ideas and accepting risk and not being afraid of failure (O'Connor, 2008). Moreover, in organizations there are other barriers able to reduce learning and maintaining social relationships (Karim \& Kaul, 2015). Youngok Kim and Liu (2015) shown that knowledge transferring - especially tacit knowledge - between a providing and a receiving unit is enabled to the extent that the two parties have a strong established relationship.

To overcome these obstacles and barriers it is necessary that the employee try to be receptive to different sources of knowledge. At this stage, updated-knowledge from external social networks is individual and tacit (related to the employee that contacts the external agent). In this regard, the literature emphasizes the importance of open-mindedness. According to some authors, as Sinkula, Baker and Noordewier (1997), this concept is considered the receptivity to new and possibly different ideas. Moreover, considering the capacity of the company members to both express different views and explore the diverse knowledge provided by other members (Tjosvold \& Poon, 1998). This leads to an atmosphere with exchange of ideas and, consequently, consideration of different points of view is generated (Cegarra-Navarro \& Sánchez-Polo, 2011) which can be useful for the development of innovations. Moreover, when there are different views, open-minded facilitates the search for more information (Tjosvold \& Poon, 1998), generating greater learning. Existing knowledge can solve the problems of the past successfully but does not guarantee that it is relevant to address future challenges (Cegarra-Navarro \& Sánchez-Polo, 2011). To do this, you need to unlearn old ways and to renew or update the knowledge base (Calantone, Cavusgil, \& Yushan, 2002), with new useful knowledge for the company. Therefore it is necessary to question existing routines (Calantone et al., 2002) in pursuit of new ideas to consider different perspectives (Slater et al., 2014). Thus, open-mindedness employees encourage development and use of internal and external social networking company in the search for new knowledge that can be useful for the organization. Then, networks will create a climate of selfmutual interest, communication and participation that will foster the efficient processing of information and generation of knowledge (Nohria \& Eccles, 1992). For this reason open-mindedness has often been linked to the development of innovations (Mitchell, Parker, \& Giles, 2012) and the use of social networks (Suseno \& Ratten, 2007).

Therefore, it is suggested that open-mindedness plays an important role in the development of both types of social networks. In this sense:

$\mathbf{H}_{2}$ : Greater degrees of open-mindedness will lead to greater use of external social networks.

$\mathbf{H}_{3}$ : Greater degrees of open-mindedness will lead to greater use of internal social networks. 


\section{Social networks, radical innovation and performance}

The relationships between inter-organizational networks, innovation performance (Bergenholtz \& Waldstrøm, 2011), innovation performance and the creation of networks for developing innovations (Ahuja, Lampert, \& Tandon, 2008) have also been studied. The findings support the notion that external and internal networks are not only determinant for radical innovations but also play an important role in organizational performance. Specially, the literature has emphasized significance of external relationships. Regarding this, Fletcher and Barrett (2001) underlined the importance of considering concrete personal relationships and networks of relations (embeddedness) in generating trust, establishing commitment, and creating and enforcing norms. Furthermore, external social network will help to achieve competitive advantages by establishing a set of rules to facilitate the achievement of the common objectives of a collective (Burt, 1992). This recognizes that social structure, such as social networks and interpersonal relationships, have a great influence on various economic and political outcomes (Adler \& Kwon, 2002).

In more detail, information obtained from the market is essential to use market resources (Batt, 2008). Decision-making, organizational performance (Kostopoulos et al., 2011) and the collaboration with external agents can identify new applications and resources, reduce development costs, shorten development cycles, and reduce financial risks that will directly contribute to financial results of the company (G. Wang, Dou, Zhu, \& Zhou, 2015). In this sense, external social network may help firms improve decision making, identify potential demand changes, technological advancements and new business opportunities, and gain a first-mover advantage (Baker, Grinstein, \& Harmancioglu, 2016). Therefore, those companies with external networks that facilitate the acquisition and use of new external knowledge for the company may allow them to conduct their operations more effectively, reduce their costs, achieve higher levels of customers' satisfaction and identify new business opportunities. This approach will result in higher profits for the company. Thus:

$\mathbf{H}_{4}$ : The use of the external social network positively impacts on financial performance.

It is widely accepted that the creation and use of new knowledge is essential for the development of new products (Kostopoulos et al., 2011). In the case of radical products, this requirement is greater because these products demand incorporation of different technology, material or new management procedures (Sorescu et al., 2003). The sources of knowledge for innovation may be inside or outside the organization, and mainly from the relationships with other agents (e.g. employees, firms, universities, research laboratories, suppliers or customers) (Youngok Kim \& Lui, 2015; Powell, 1990). That is why some authors consider that social network is highly related to the launch strategy for innovative products (Hsieh \& Tsai, 2007). Network cooperation across a wide range of external actors and sources has a positive impact on innovation performance of enterprises (Zeng, Xie, \& Tam, 2010). Collaboration with external agents promotes knowledge transfer from the outside that can be used to improve the innovation process of the company (G. Wang et al., 2015). Besides, the generation of new products through innovation processes carries with it involving different members of the internal network, who are committed and cooperate between them (Corsaro, Cantù, \& Tunisini, 2012). This means that despite the improvement on communications means, face-to-face relationships are still particularity important for innovation (Nohria \& Eccles, 1992).

This will create and share knowledge individually and transfer it to other members of the company, which will generate new and common insights and new key capabilities (Jiménez-Jimenez, Valle, \& Hernandez-Espallardo, 2008). There is evidence that knowledge acquisition is positively related to product innovation (Sherman, Berkowitz, \& Souder, 2005). Consequently, knowledge acquired from external social networks is highly correlated with product innovations (Subramaniam \& Youndt, 2005). It has also been demonstrated that links of social interaction, trust and reliability, at the business unit level, have a positive influence on product innovation ( $\mathrm{Wu}$, Chang, \& Chen, 2008). Additionally, the exchange of ideas and knowledge-sharing among an organization's employees is related to product innovation (Calantone et al., 2002). Furthermore, the interactions between 
departments and the cooperation of employees are clear determinant factors in new product development (Moran, 2005). Thus, internal social networks are also related to the generation of product innovations.

However, although the external social network is relevant for radical innovations, this relationship is mediated by the internal social network. It is clear that the information acquired from different external sources will be captured by the internal staff of the company, which does not necessarily have to be involved in innovation processes. If that internal agent is not connected to other members of the organization, this valuable knowledge will not contribute to its purpose (Lesser, 2000). It explains why companies which choose to use external networks also promote the development of internal networks. Furthermore, the use of external networks will enrich the knowledge of employees through internal networks, which will also translate into a learning organization capable of developing innovations. Thus:

H$_{5}$ : The impact of external social network on radical innovation is mediated by the internal social network.

Figure 1 summarizes the hypotheses raised in this study.

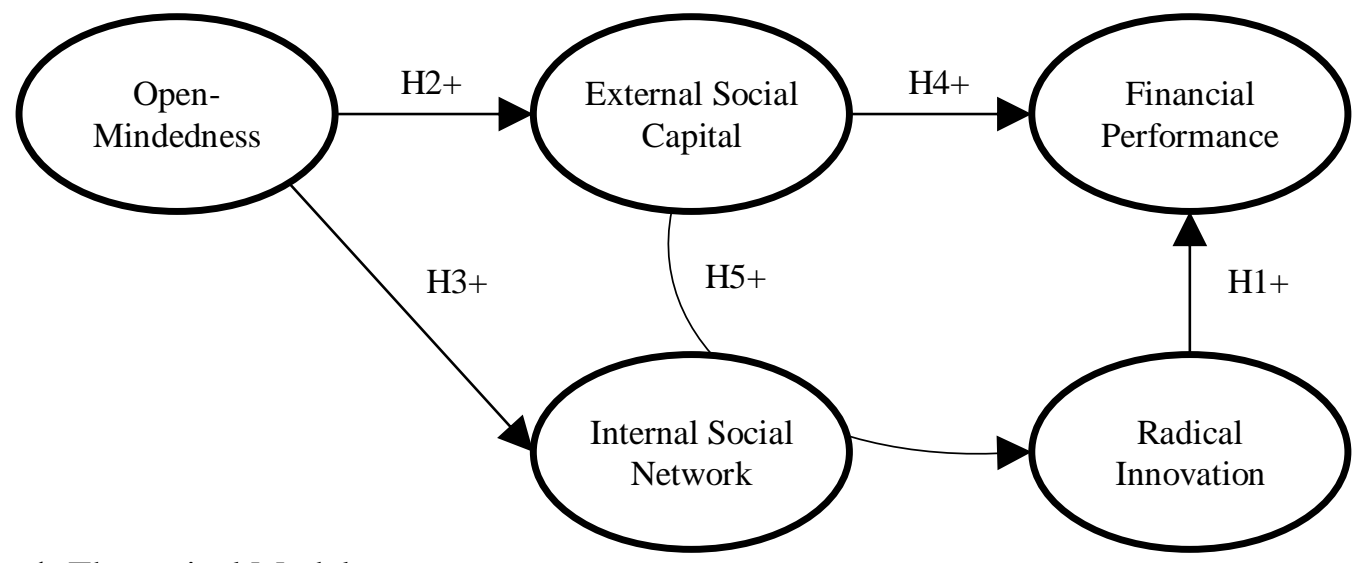

Figure 1. Theoretical Model

\section{Method}

\section{Data collection procedure and sample}

In this study, like others (e.g., Slater et al., 2014), a sample of different sectors and industries of Brazilian organizations is used. Brazil combines the particular characteristics of an emerging country, such as low disposable income, market turbulence, underdeveloped institutional frameworks, and lack of infrastructure (Peng, Wang, \& Jang, 2008). Despite having a natural advantage of being located in the markets they serve, the aforementioned characteristics of the Brazilian national business system pose threats to local players (Sheth, 2011). Therefore, this study helps to understand some of the determinants of performance in a context of a developing country.

The database of the participant firms was provided by a non-governmental agency. For a profile of companies in the sample, below are some of its main features. In relation to the size, companies vary from small to large (25.6\% of the sample have up 400 employees, $26.8 \%$ between 401 and 800 employees, $14.2 \%$ between 801 and 1200 employees, and $33.4 \%$ have more than 1200 employees). With respect to age, $3.5 \%$ of companies have less than 10 years in the market, $33 \%$ have between 10 and 30 years, 35.2 have between 31 to 50, while the oldest group of companies consists of companies with more than 50 years of existence (85.4\%). In terms of economic sector, the main group of companies are in the manufacturing sector $(65.8 \%)$, followed by services sector $(9.6 \%)$ and transportation, communication and electric and gas sector (8.6\%). In addition, $55.6 \%$ of companies in the sample have manufacturers as main clients, and, $30.2 \%$ have focus on distributors, and dealers. Finally, about covered market, 
$44.2 \%$ of companies focus only on the domestic market, $25.9 \%$ are dedicated exclusively to the international market and $29.9 \%$ on both domestic and international markets.

A survey was administered to managers of the companies mentioned above, which provides a comprehensive view of the company, both in areas of innovation and related to aspects of social networks and financial results for the company. CEOs from the list of firms acquired from the Dunn \& Bradstreet were selected. We followed Homburg, Klarmann, Reimann and Schilke (2012) recommendations for the use of single key informant.

A review of the literature on the most appropriate scales proposed for this work was done. Having identified, validated and tested scales by relevant literature, we proceeded to its translation into Portuguese by a bilingual agent. Subsequently, two other experts in the field assessed the content, so validity of the questionnaire was measured to certify its effectiveness. Later, we back-translated the questionnaire to check its consistency with the original scales (Craig \& Douglas, 2005).

A pretest of the questionnaire was conducted in 12 companies to check that there were no problems in understanding the items or the statement of the issues (Churchill, 1979).

Finally, the questionnaire was sent to 3,000 companies through a postal survey. After the collection process and purification of incomplete questionnaires, 361 completed questionnaires were obtained, representing a response rate of $12 \%$, which is acceptable and similar to that obtained in other studies in developing country (Sousa \& Lengler, 2009). From those 361, a total of 324 firms declared in the questionnaire that their main commercial activities were B2B. To ensure the relevance of this discussion in a B2B context and to avoid a possible bias from different perspectives of network emphasis, the $37 \mathrm{~B} 2 \mathrm{C}$ firms were eliminated from the final sample.

The issue of non-response bias is an important topic in marketing research projects. To explore this issue, it was found possible differences depending on the response time. We consider questionnaires to be late if they were the final $25 \%$ to be received, and early if they were in the first $75 \%$ to arrive (Weiss \& Heide, 1993). Additionally, non-response bias was analyzed between sample companies and population companies (profitability, sales, size, age and industry sectors - SIC) using t-student and chisquare tests without significant differences. Therefore, there is an absence of bias and we have a valid sample to carry out our study.

\section{Measures}

The research model of this work has five main constructs, which have been measured with the following scales (see Table 1).

Open-mindedness. We used the scale proposed by Baker and Sinkula (1999) to measure the openmindedness level of the firm. This measure seeks to know to what extent the organization proactively questions even its older routines, assertions and company beliefs, replacing or removing obsolete knowledge.

Internal and external social networks. Baker, Grinstein and Harmancioglu (2016)'s scale was used for measuring the degree to which employees explore social external and internal networks to have access to new ideas, answer problems, obtain different points of view, discover opportunities and obtain new information about their business.

Radical innovation. Refers to the importance of the changes made in new products and services offered by the company. In this case, we used the scale of Subramaniam and Youndt (2005) for this measure.

Financial performance. The study's dependent measure was measured by asking respondents about sales and profitability relative to the competition (Sampaio, Simões, Perin, \& Almeida, 2011). 
Control variables. We used three control variables that are frequently used in studies of this area (e.g., Stam et al., 2014; Youngok Kim \& Lui, 2015): age, size and sector. To measure them, it has been used the number of years since its foundation, the number of employees of the company, and the economic sector (using the Standard Industrial Classification) of each firm.

Table 1

Summary of Measurement Constructs: Confirmatory Factor Analysis and Reliability of Scales

\begin{tabular}{ccc}
\hline Item description & $\begin{array}{c}\text { Standardized } \\
\text { Loadings }\end{array}$ & $t$-values \\
\hline
\end{tabular}

Open Mindedness (Baker \& Sinkula, 1999)

- We are not afraid to reflect critically on the shared assumptions we have about the way we do business.

- Our business unit places a high value on open-mindedness.

0.753

- Managers encourage employees to "think outside of the box".

0.831

- Original ideas are highly valued in this organization.

0.763

(scale: $1=$ strongly disagree; $7=$ strongly agree $)$

\section{External Social Network (Baker et al., 2016)}

- Our employees are encouraged to network with experts outside of the company to find new ways to solve problems and exploit opportunities.

- Our employees' decision-making process includes integrating knowledge and expertise from outside of our company.

- Our employees are encouraged to exchange ideas with external sources whose point of view may be different than ours.

- Our employees work with knowledgeable people wherever they can find them to "make sense" of information.

(scale: $1=$ strongly disagree; $7=$ strongly agree)

\section{Internal Social Network (Baker et al., 2016)}

- Our employees are expected to collaborate with each other to find new ways to solve problems and exploit opportunities.

- Our employees' decision-making process includes integrating knowledge from various parts of our company.

- Our employees are encouraged to improve ideas by sharing them with employees that have a variety of perspectives.

- Our employees work together to "make sense" of information.

(scale: $1=$ strongly disagree; $7=$ strongly agree) 
Table 1 (continued)

\begin{tabular}{lcc}
\hline \multicolumn{1}{c}{ Item description } & $\begin{array}{c}\text { Standardized } \\
\text { Loadings }\end{array}$ & t-values \\
\hline Radical Innovation (Subramanian \& Youndt, 2005) & & \\
- Innovations that make your current product/service line obsolete. & 0.822 & \\
- Innovations that make your expertise in current products/services obsolete. & 0.843 & 11.968 \\
- Innovations that fundamentally change your prevailing products/services. & 0.608 & 10.312 \\
(scale: $1=$ strongly disagree; $7=$ strongly agree) & & \\
\hline Financial performance (Sampaio et al., 2011) & & \\
- Sales & 0.716 & \\
- Profitability & 0.748 & 5.475 \\
(scale: $1=$ Much lower; $7=$ Much higher) & & \\
\hline
\end{tabular}

\section{Measure validation}

Missing data were deleted using listwise. In this instance, any case with missing data on one or more of the variables was eliminated from the analysis. We tested the assumptions of multivariate analysis, i.e., normality, multicollinearity, and homoscedasticity, for the variables used in the measurement model. Multivariate multicollinearity was exanimated with the variance inflation factor (VIF). All the VIF values in this study were smaller than 4, which is the common cut-off criterion, indicating no multicollinearity problem. We confirmed homoscedasticity through analysis of the normal probability plot and plots of the residuals against the independent variables. The normality of each item also tested with the Kolmogorov-Smirnov presented acceptable values.

To analyze whether the study had adequate scales for hypothesis testing, a confirmatory factor analysis (CFA) of the five scales was conducted (Anderson \& Gerbing, 1988) using AMOS 16. First, the fits of the CFA model $(\chi 2=198.151, \mathrm{df}=109, \chi 2 / \mathrm{df}=1.818 ; \mathrm{RMSEA}=0.050 ; \mathrm{GFI}=0.936 ; \mathrm{AGFI}=.910$; $\mathrm{TLI}=0.964 ; \mathrm{CFI}=0.971)$ were adequate (Byrne, 2001). Secondly, reliability was computed with Bagozzi and Yi's (1998) composite reliability (CR) index and with Fornell and Larcker (1981) average variance extracted (AVE) index (see Table 2). The values obtained for both measures exceed 0.7 (for CR) and 0.5 (for AVE) (Bagozzi \& Yi, 1998). Moreover, the estimations of each item were positive and significant, which provides evidence of convergent validity (Bagozzi \& Yi, 1998). Third, discriminant validity was tested using two different procedures recommended by Anderson and Gerbing (1988) and Fornell and Larcker (1981). On the one hand, discriminant validity was indicated since the confidence interval ( \pm 2 S.E.) around the correlation estimate between any two latent indicators never included 1.0 (Anderson \& Gerbing, 1988). On the other hand, discriminant validity was tested by comparing the square root of the AVEs for a particular construct with its correlations with the other constructs (Fornell \& Larcker, 1981). Both tests reveal evidence of discriminant validity among the constructs.

Finally, two procedures to test the extent of common method bias were conducted (Podsakoff, MacKenzie, Lee, \& Podsakoff, 2003). Initially, Harman's single factor test was conducted with CFA approach. The fit indices obtained for this model were very poor $(\chi 2=1299.079 ; \mathrm{df}=119 ; \chi 2 / \mathrm{df}=10.917$; RMSEA $=0.175 ; \mathrm{GFI}=0.630 ; \mathrm{AGFI}=0.524 ; \mathrm{TLI}=0.559 ; \mathrm{CFI}=0.614)$. Finally, we checked the effects of an unmeasured latent method factor in our empirical model (Podsakoff et al., 2003). The hypothesized relationships in the model were not affected by the inclusion of a single factor in the structural model. Furthermore, none of the path coefficients between the single source factor and the construct indicators was significant. Therefore, it seems that common method variance had not biased our measures, providing validity for them. 
Table 2

Construct Correlation Matrix

\begin{tabular}{lcccccccccc}
\hline Construct & Mean & SD & $\boldsymbol{\alpha}$ & $\mathbf{C R}$ & \multicolumn{7}{c}{ Correlation Matrix } \\
\cline { 7 - 10 } & & & & & $\mathbf{1}$ & $\mathbf{2}$ & $\mathbf{3}$ & $\mathbf{4}$ & $\mathbf{5}$ \\
\hline 1. Open Mindedness & 5.37 & 1.09 & 0.86 & .86 &. $\mathbf{7 8}$ & & & & \\
2. External Social Network & 4.80 & 1.27 & 0.91 & .91 & $.523^{* *}$ & .84 & & & \\
3. Internal Social Network & 5.15 & 1.18 & 0.90 & .89 & $.656^{* *}$ & $.492^{* *}$ & .83 & & \\
4. Radical innovation & 3.26 & 1.28 & 0.79 & .80 & $.182^{* *}$ & .090 & $.181^{* *}$ & .77 & \\
5. Financial performance & 5.10 & 1.14 & 0.70 & .70 & $.299^{* *}$ & $.236^{* *}$ & $.215^{* *}$ & $.194^{* *}$ & .73 \\
\hline
\end{tabular}

Note. Diagonal elements (in bold) are the square root of the average variance extracted (AVE). $* * \mathrm{p}<0.01$.

\section{Results}

To test our research model and hypotheses that flow from it, the methodology used structural equation model (Jöreskog \& Sörbom, 1996). The adjustment structural model results were satisfactory $\left(\chi^{2}=260.263 ; d f=159 ; \chi 2 / \mathrm{df}=1.637 ; \mathrm{RMSEA}=0.044 ; \mathrm{GFI}=0.929 ; \mathrm{AGFI}=0.906 ; \mathrm{TLI}=0.961 ; \mathrm{CFI}=\right.$ 0.667). The coefficient of determination value for the criterion variable financial performance was 0.226. Figure 2 illustrates our conceptual framework of the role of open-mindedness in facilitating internal and external social networks, which in turn facilitates radical innovation and promotes a more effective financial performance.

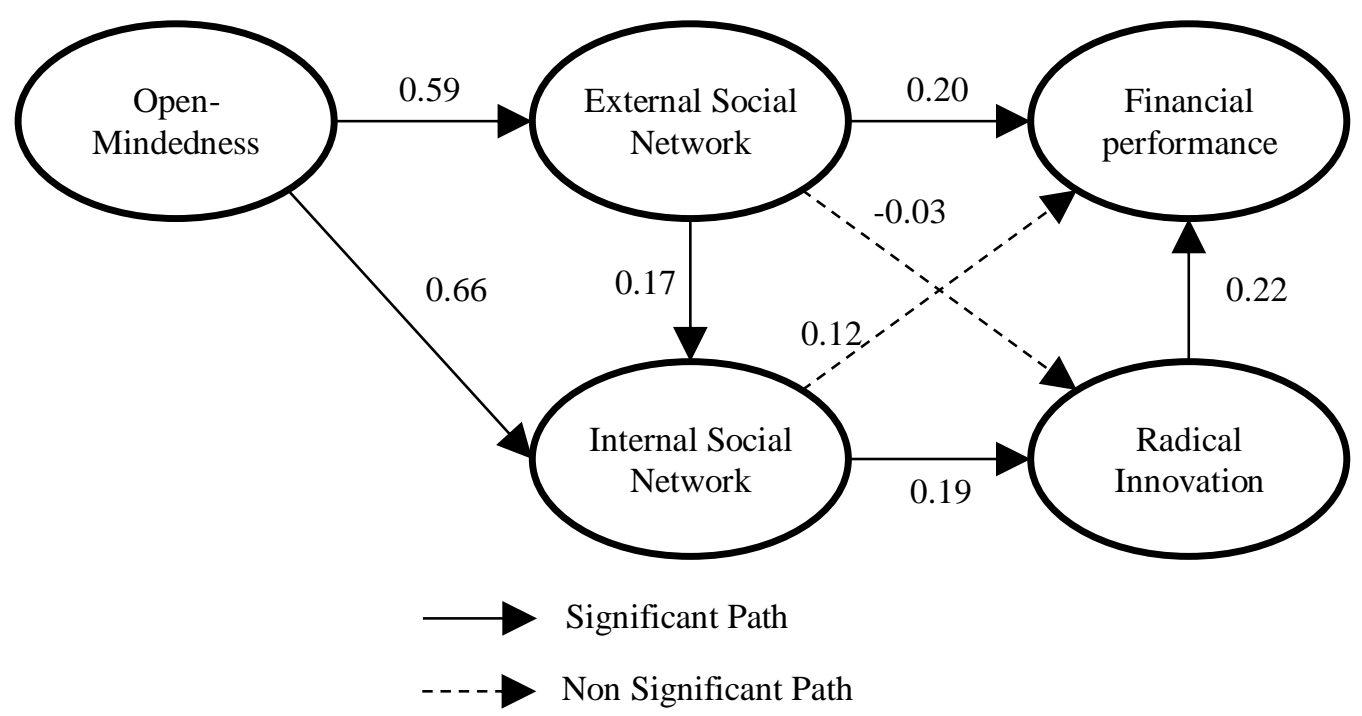

Figure 2. Measure Model

The results obtained are presented in Table $3 . \mathrm{H}_{1}$ was supported since radical innovation had a positive and direct effect on financial performance $(\beta=0.22, p<0.001)$. This reinforces the idea that radical new product helps companies to attain a competitive advantage under a context or high turbulence and emerging market economies.

The relationship between open-mindedness and external network was positive and significant $(\gamma=0.59, \mathrm{p}<0.001)$, supporting $\mathrm{H}_{2}$ and the idea that open-mindedness is a key driver of the creation of the relationships between firms and external stakeholders, partners, and competitors. Our findings also found a significant relationship between open-mindedness and internal social network $\left(\mathrm{H}_{3} ; \gamma=0.66\right.$, 
$\mathrm{p}<0.001$ ), which suggests a combination of networks together with shared norms, values and understandings facilitates co-operation within and among groups. Thus, the impact of open-mindedness on the internal social network is potentially mitigated by the extent to which external social capital exists.

The external social network, as predicted, had a direct impact on financial performance $(\beta=0.20$, $\mathrm{p}<0.05)$. Therefore, we conclude that $\mathrm{H}_{4}$ was supported. Although no hypothesis was proposed for the internal social network $\rightarrow$ financial performance relationship, we included it in the model to control for its possible interference in the impact of radical innovation and the external social network on financial performance. It had no significant effect $(\beta=0.12, \mathrm{p}>0.05)$. This result suggests a possible mediating role of radical innovation on the internal social network and financial performance relationship.

To evaluate $\mathrm{H}_{5}$, we followed the approached proposed by Iacobucci, Saldanha and Deng (2007). As shown in Table 3, external social networks have a positive and significant impact on internal social networks $(\beta=0.17, \mathrm{p}<0.01)$; and internal social networks have a positive effect on radical innovation $(\beta=0.19, \mathrm{p}<0.05)$. The results showed an indirect effect of the external social network $(\kappa=0.03, \mathrm{p}<0.05)$ on radical innovation through the internal social network. In addition, Sobel z-test for the mediating effect of internal social networks $(z=2.759 ; \mathrm{p}<0.01)$ was also significant. These results confirmed $\mathrm{H}_{5}$, showing that the internal social network has a mediating effect in the relationship between the external social network and radical innovation. As the direct impact of the external social network on radical innovation was not significant, the results meet the conditions for a full mediation of the internal social network on this relationship.

Table 3

\section{Main Results}

\begin{tabular}{|c|c|c|}
\hline \multirow[t]{2}{*}{ Linkages in the model } & \multicolumn{2}{|c|}{ Standardized parameter estimates } \\
\hline & Estimate & $t$-value \\
\hline \multicolumn{3}{|l|}{ Direct effects } \\
\hline $\mathrm{H}_{1} \quad$ Radical innovation $\rightarrow$ Financial performance & 0.22 & $3.14^{* *}$ \\
\hline $\mathrm{H}_{2} \quad$ Open-mindedness $\rightarrow$ External social network & 0.59 & $9.47^{* * *}$ \\
\hline $\mathrm{H}_{3} \quad$ Open-mindedness $\rightarrow$ Internal social network & 0.66 & $8.70^{* * *}$ \\
\hline $\mathrm{H}_{4} \quad$ External social network $\rightarrow$ Financial performance & 0.20 & $2.45^{*}$ \\
\hline \multicolumn{3}{|l|}{ Indirect effects } \\
\hline $\mathrm{H}_{5} \quad$ External social network $\rightarrow$ Radical innovation & $0.03^{*}$ & \\
\hline \multicolumn{3}{|l|}{ Other direct paths } \\
\hline External social network $\rightarrow$ Internal social network & 0.17 & $2.81^{* *}$ \\
\hline Internal social network $\rightarrow$ Radical innovation & 0.19 & $2.40^{*}$ \\
\hline External social network $\rightarrow$ Radical innovation & -0.03 & -0.34 \\
\hline Internal social network $\rightarrow$ Financial performance & 0.12 & 1.47 \\
\hline \multicolumn{3}{|l|}{ Control variables } \\
\hline Age $\rightarrow$ Financial performance & -0.12 & $-1.97^{*}$ \\
\hline Size $\rightarrow$ Financial performance & 0.06 & 1.00 \\
\hline Sector $\rightarrow$ Financial performance & -0.03 & -0.51 \\
\hline
\end{tabular}

Note. The indirect effects were estimated by applying bootstrapping (1000 bootstrap sample with $90 \%$ bias-corrected confidence interval) procedure (Iacobucci, D., Saldanha, N., \& Deng, X. (2007). A meditation on mediation: evidence that structural equations models perform better than regressions. Journal of Consumer Psychology, 17(2), 139-153. http://dx.doi.org/10.1016/S1057-7408(07)70020-7).

${ }^{*} \mathrm{p}<0.05 ;{ }^{* *} \mathrm{p}<0.01$ 


\section{Discussion and Conclusions}

This research provides a comprehensive overview of the factors influencing the performance of companies in a large emerging market economy: open-mindedness, social capital and radical innovation (Figure 1). In this context, companies must face challenges from the environment, which demands that companies develop higher levels of quality and variability and constant innovation in its products and services. To achieve this, companies must address innovation processes based not only on cooperation and exchange of information with agents from internal and external networks (Powell, 1990), but they also need an organizational culture that promotes the receptiveness to new ideas. This study takes Resource-based view and organizational learning approach as the foundation to investigate some organizational behaviors (open-mindedness and social networks) and radical innovations as several antecedents of organizational performance.

Under the open innovation paradigm, companies need learning capabilities to obtain new radical products and services to help them improve their financial results. The results support the argument that organizations need to generate new knowledge from internal and external sources in order to generate new ideas and design new approaches that lead to radical innovations. While previous studies confirm the relationship of learning strategies and organizational innovation (Chang \& Cho, 2008), this research tries to focus on radical innovations that demand higher levels of the novelty of the acquired knowledge. Thus, this study examines the effect of both internal and external social networks for promoting radical innovations and, ultimately, improving the financial performance of the company. Moreover, it discusses how companies should stimulate employees' behavior towards greater use of social networks. Some research has shown that certain cognitive characteristics and employee motivation will influence participation in social networks (Osman-Gani \& Rockstuhl, 2008). Other studies have indicated that HR practices can promote willingness to transfer knowledge and learning (Collins \& Smith, 2006). From the point of view of the radical innovation, open-mindedness has not yet been treated with the necessary interest, to the best of the authors' knowledge. Therefore, our findings corroborate the fact that openmindedness allows employees to have a greater willingness to cooperate in internal and external networks in order to generate new knowledge. Furthermore, this study adds to the literature empirical evidence of how open-mindedness promotes the creation of new knowledge for radical innovations through the utilization of social networks in the context of large emerging market economy.

In line with the results of theoretical model shown in Figure 2, the radical innovation becomes a source of competitive advantage for companies in emerging economies. These new products or services, different from those existing in the market, can improve the performance of companies with greater force. This means that despite its risks and costs, radical innovation facilitates obtaining higher benefits for organizations. This finding is consistent with previous studies, which indicate that companies that develop radical innovations have higher levels of performance (Brown \& Eisenhardt, 1995). In the context of the Brazilian industrial sector and considering the ideas of Slater, Mohr and Sengupta (2014), a possible strategy to follow is to explore new and greater sources of information to generate ideas for radical innovations.

The results from testing the empirical model show that open-mindedness is positively related to the use of internal and external social networks. The receptiveness to new ideas facilitates that employees recognize the value of knowledge and beliefs of other agents in the social network that could be useful for the company (Sanchez-Casado et al., 2016). This means that those companies that are more predisposed to capture new ideas are going to try to encourage the use of both internal and external networks. Contrary, employees would not value or would not be willing to interact with other agents. A plausible explanation for this is that to implement social networks, organizations require a level of openness and transparency, which needs to come from listening and embracing others' ideas rather than simply imposing our thoughts.

Our results have also shown that the effects of open-mindedness on internal social network are mediated by the external social network. This suggests that open-mindedness is an important antecedent 
of the process of converting external social capital into internal social capital. Moreover, the promotion of external networks will encourage the creation of new internal networks with the aim of using the knowledge acquired outside the company. What this could mean for internal social capital is that before new networks can be implemented, old networks should be reviewed and challenged. It is possible to establish new relations of communication between members of the company that previously did not exist (such as between sales personnel, agents that collaborate with external entities and management innovation), not limited to personal relationships, mostly informal, to share information. These results are also consistent with the literature focused on learning orientation and results (Baker \& Sinkula, 1999; Kropp et al., 2006), since open-mindedness is a way of learning.

The findings also highlight that financial performance is an outcome of external social networks. This finding sustains and reinforces the role attributed by previous literature to this social capital. In this regard, successful firms are those who learn how to gain from external linkages without creating enemies or opportunistically (Powell \& Brantley, 1992). As Baker and Sinkula (1999) suggest, employees should think beyond their normal work schedule to find new ideas to understand the environment and increase business performance. For this reason, a network operates as a locus of innovation because it offers timely access to knowledge and resources that are otherwise unavailable, while also testing internal expertise and learning capabilities (Powell et al., 1996). Therefore, the establishment of relations with other agents outside the organization will provide better ideas to significantly adapt to the changing environment and obtain higher performance levels.

There are surprising results when we look more closely at the insignificant relation between social network and radical innovation (see Figure 2). The results suggest that although the indirect effect of external social networks on radical innovation via internal social network is statistically significant, external social networks do not directly influence the existence of radical innovation. A plausible explanation for this is that open-mindedness companies develop more radical innovations through the interaction with members of its internal social network and indirectly through its external social network. In this regard, we follow Rhee, Park, and Lee (2010), who argue that open-mindedness, as a learning orientation characteristic, can be encouraged when organizations purporting to act entrepreneurially. According to these authors, organizational learning facilitates the creation of knowledge and technology leading to innovations (Rhee, Park, \& Lee, 2010). When firms are open to adopt new processes, to review its procedures and exercise the unlearning process, they are more likely to achieve radical innovations from the external sources. Therefore, employees should consider the current internal practices and analyze whether they are valid in changing environments. The introduction of new practices will facilitate process improvement and create new products that increase the performance of the company. Furthermore, social networks play a crucial role for organizations as means of conducting information that provides opportunities and constraints for organizations on the networks (Gulati, 1998). Radical innovations will happen only when the external knowledge (from material suppliers or customers with unmet needs) is transferred to the company and is interiorized and applied by employees responsible for the development of new products and designs. Without a strong social internal network, all external knowledge will be useless, because it would not be transmitted to those involved in the innovation process.

The conclusions above suggest that open-mindedness may help companies to direct their efforts to create internal and external social networks. Although this study focuses on Brazilian organizations, many companies located in other countries have confronted the challenges inherent in creating internal and external social networks. For example, Argentina and Brazil are both geographically and historically close, and encompass all possible dimensions: economy, trade, culture, education and tourism (Melé, Debeljuh, \& Arruda, 2006). Therefore, the findings of this study may also help other emerging economies such as Argentina, to understand the nature and function of open-mindedness in the implementation of internal and external social networks; which in turn is a necessary step towards understanding whether internal and external social networks can be used and how they might be used to improve financial performance. We believe that this is an important point, as the potential for any company to improve financial performance will depend substantially on its ability to provide a stimulus for using internal and external social networks. 
Some conclusions can be drawn for company managers. Initially, we suggest that a posture of an open mindedness should be developed in the company, because of its positive indirect effect on firm performance. Thus, organizations must create a culture that encourages the generation of new ideas about markets, technology and environment with rewards and prizes (Sinkula, Baker, \& Noordewier, 1997). In addition, companies must not only create new products, they have high levels of radicalness. Some studies, such as Tellis, Prabhu and Chandy (2009), show that the R \& D activities and the organizational culture of companies have a positive impact on radical innovation. That is why, they must invest in the development of radically different products to existing ones, which will require the search for new ideas from inside, such as in other departments, and outside the company with cooperative partnerships with universities and technological institutes, to have a greater breadth of knowledge and share the risks and take part in the latest findings of scientific research.

This work also has some limitations that are targeted to be addressed in future research avenues. First, the generalization of the results should be treated with caution when using a sample of a developing country that could present differences with other more developed countries, for example in terms of culture or level of innovation. Another limitation related to type of studies is its transversal character in a moment of time. In this case, some of the relationships raised need time to be developed, such as the effect of open-mindedness on the use of social networks or the effect of radical innovation on the financial results of the company. Hence studies are needed with a longitudinal design. In addition, we must reflect on the discussion about a single industry sample and a multi-industry sample. In this study, we considered that a single industry sample could restrict the scope of the findings compared to a multiindustry sample (Li \& Greenwood, 2004). Finally, this work has not controlled the technological level of the company or sector. However, certain companies need to strengthen their technological capacity further to achieve competitive advantage by market needs.

Nonetheless, we suggest that future research should analyze the stability of the same phenomena in specific industries. In the present study, we investigated only the direct effects of radical innovation on firms' performance. In the light of the results reported here, we also suggest that future research should be addressed to investigate the mediating role of networks on the open-mindedness / radical innovation relationship. Another important aspect would be to analyze the issue of incremental innovations. While radical innovations require a greater amount of new knowledge, incremental innovations also require internal and external learning with more frequency due to the processes of continuous improvement and product improvement. Finally, the use of social media applications could also have a main role explaining some of these relationships. On the one hand, social media technologies can enable companies interact with both their own employees and other external members of the network with innovative potentialities. On the other hand, they could help to the diffusion of radical innovations among individuals in a social system to improve organizational performance. Despite the limitations of this study, our work contributes to the advance of the literature in many ways, especially in relation to the understanding of the role played by learning orientation and radical innovation in financial performance.

\section{References}

Aboulnasr, K., Narasimhan, O., Blair E., \& Chandy, R. (2008). Competitive response to radical product innovations. Journal of Marketing, 72(3), 94-110. http://dx.doi.org/10.1509/jmkg.72.3.94

Adler, P. S., \& Kwon, S.-W. (2002). Social capital: prospects for a new concept. Academy of Management Review, 27(1), 17-40. http://dx.doi.org/10.5465/AMR.2002.5922314

Ahuja, G., Lampert, M. C., \& Tandon, V. (2008). Moving beyond Schumpeter: management research on the determinants of technological innovation. Academy of Management Annals, 2(1), 1-98. http://dx.doi.org/10.1080/19416520802211446 
Anderson, J. C., \& Gerbing, D. W. (1988). Structural equation modelling in practice: a review and recommended two-step approach. Psychological Bulletin, 103(3), 411-423. http://dx.doi.org/10.1037/0033-2909.103.3.411

Bagozzi, R. P., \& Yi, Y. (1998). On the evaluation of structural equation model. Journal of the Academy of Marketing Science, 16(1), 74-94. http://dx.doi.org/10.1007/BF02723327

Baker, W. E., Grinstein, A., \& Harmancioglu, N. (2016). Whose innovation performance benefits more from external networks: entrepreneurial or conservative firms? Journal of Product Innovation Management, 33(1), 104-120. http://dx.doi.org/10.1111/jpim.12263

Baker, W. E., \& Sinkula, J. M. (1999). The synergistic effect of market orientation and learning orientation on organizational performance. Journal of the Academy of Marketing Science, 27(4), 411-427. http://dx.doi.org/10.1177/0092070399274002

Batt, P. J. (2008). Building social capital in networks. Industrial Marketing Management, 37(5), 487 491. http://dx.doi.org/10.1016/j.indmarman.2008.04.002

Bayus, B. L., Erickson, G., \& Jacobson, R. (2003). The financial rewards of new product introductions in the personal computer industry. Management Science, 49(2), 197-210. https://doi.org/10.1287/mnsc.49.2.197.12741

Beck, M., Lopes-Bento, C., \& Schenker-Wicki, A. (2016). Radical or incremental: where does R\&D policy hit? Research Policy, 45(4), 869-883. http://dx.doi.org/10.1016/j.respol.2016.01.010

Benner, M. J., \& Tushman, M. L. (2003). Exploitation, exploration, and process management: the productivity dilemma revisited. Academy of Management Review, 28(2), 238-256. http://dx.doi.org/10.5465/AMR.2003.9416096

Bergenholtz, C., \& Waldstrøm, C. (2011). Inter-organizational network studies - a literature review. Industry and Innovation, 18(6), 539-562. http://dx.doi.org/10.1080/13662716.2011.591966

Boso, N., Story, V. M., Cadogan, J. W., Annan, J., Kadić-Maglajlić, S., \& Micevski, M. (2016). Enhancing the sales benefits of radical product innovativeness in internationalizing small and medium-sized enterprises. Journal of Business Research, 69(11), 5040-5045. http://dx.doi.org/10.1016/j.jbusres.2016.04.077

Bowey, J. L., \& Easton, G. (2007). Net social capital processes. Journal of Business \& Industrial Marketing, 22(3), 171-177. http://dx.doi.org/10.1108/08858620710741878

Brown, S. L., \& Eisenhardt, K. M. (1995). Product development: past research, present findings, and future directions. Academy of Management Review, 20(2), 343-378. http://dx.doi.org/10.5465/AMR.1995.9507312922

Burgess, S. M., \& Steenkamp, J.-B. E. M. (2006). Marketing renaissance: how research in emerging consumer markets advances marketing science and practice. International Journal of Research in Marketing, 23(4), 337-356. http://dx.doi.org/10.1016/j.ijresmar.2006.08.001

Burt, R. S. (1992). The social structure of competition. In N. Nohria \& R. G. Eccles (Eds.), Networks and organizations: structure, form, and action (pp. 57-91). Boston: Harvard Business School Press.

Byrne, B. M. (2001). Structural equation modeling with AMOS: basic concepts, applications, and programming. Mahwah, NJ: Lawrence Erlbaum Associations Inc.

Calantone, R. J., Cavusgil, S. T., \& Yushan, Z. (2002). Learning orientation, firm innovation capability, and firm performance. Industrial Marketing Management, 31(6), 515-524. http://dx.doi.org/10.1016/S0019-8501(01)00203-6 
Cegarra-Navarro, J.-G., \& Sánchez-Polo, M. T. (2011). Influence of the open-mindedness culture on organizational memory: an empirical investigation of Spanish SMEs. The International Journal of Human Resource Management, 22(1), 1-18. http://dx.doi.org/10.1080/09585192.2011.538963

Chandy, R. K., \& Tellis, G. J. (1998). Organizing for radical product innovation: the overlooked role of willingness to cannibalize. Journal of Marketing Research, 35(4), 474-487. http://dx.doi.org/10.2307/3152166

Chang, D. R., \& Cho, H. (2008). Organizational memory influences new product success. Journal of Business Research, 61(1), 13-23. http://dx.doi.org/10.1016/j.jbusres.2006.05.005

Chesbrough, H. W. (2003). The logic of open innovation: managing intellectual property. California Management Review, 45(3), 33-58. http://dx.doi.org/10.2307/41166175

Churchill, J. L. C. (1979). A paradigm for developing better measures of marketing construct. Journal of Marketing Research, 16(1), 64-73. http://dx.doi.org/10.2307/3150876

Coleman, J. S. (1988). Social capital in the creation of human capital. American Journal of Sociology, 94, S95-S120. Retrieved from http://www.journals.uchicago.edu/doi/pdfplus/10.1086/228943

Collins, C. J., \& Smith, K. G. (2006). Knowledge exchange and combination: the role of human resource practices in the performance of high-technology firms. Academy of Management Journal, 49(3), 544-560. http://dx.doi.org/10.5465/AMJ.2006.21794671

Corsaro, D., Cantù, C., \& Tunisini, A. (2012). Actors' heterogeneity in innovation networks. Industrial Marketing Management, 41(5), 780-789. http://dx.doi.org/10.1016/j.indmarman.2012.06.005

Craig, C. S., \& Douglas, S. P. (2005). International marketing research. Chichester, UK: John Wiley.

Cuevas-Rodríguez, G., Cabello-Medina, C., \& Carmona-Lavado, A. (2014). Internal and external social capital for radical product innovation: do they always work well together? British Journal of Management, 25(2), 266-284. http://dx.doi.org/10.1111/1467-8551.12002

Datta, A., \& Jessup, L. M. (2013). Looking beyond the focal industry and existing technologies for radical innovations. $\quad$ Technovation, 33(10/11), 355-367. http://dx.doi.org/10.1016/j.technovation.2013.05.001

Dittrich, K., \& Duysters, G. (2007). Networking as a means to strategy change: the case of open innovation in mobile telephony. Journal of Product Innovation Management, 24(6), 510-521. http://dx.doi.org/10.1111/j.1540-5885.2007.00268.x

Dombrowski, C., Kim, J. Y., Desouza, K. C., Braganza, A., Papagari, S., Baloh, P., \& Jha, S. (2007). Elements of innovative cultures. Knowledge and Process Management, 14(3), 190-202. http://dx.doi.org/10.1002/kpm.279

Easterby-Smith, M., Crossan, M., \& Nicolini, D. (2000). Organizational learning: debates past, present and future. Journal of Management Studies, 37(6), 783-796. http://dx.doi.org/10.1111/14676486.00203

Fletcher, R., \& Barrett, N. (2001). Embeddedness and the evolution of global networks: an Australian case study. Industrial Marketing Management, 30(7), 561-573. http://dx.doi.org/10.1016/S00198501(99)00120-0

Forés, B., \& Camisón, C. (2016). Does incremental and radical innovation performance depend on different types of knowledge accumulation capabilities and organizational size? Journal of Business Research, 69(2), 831-848. http://dx.doi.org/10.1016/j.jbusres.2015.07.006 
Fornell, C., \& Larcker, D. F. (1981). Evaluating structural equation models with unobservable variables and measurement error. Journal of Marketing Research, 18(1), 39-50. http://dx.doi.org/10.2307/3151312

García, R., \& Calantone, R. (2002). A critical look at technological innovation typology and innovativeness terminology: a literature review. Journal of Product Innovation Management, 19(2), 110-132. http://dx.doi.org/10.1111/1540-5885.1920110

Grant, R. M. (1996). Toward a knowledge-based theory of the firm. Strategic Management Journal, 17(S2), 109-122. http://dx.doi.org/10.1002/smj.4250171110

Gulati, R. (1998). Alliances and networks. Strategic Management Journal, 19(4), 293-317. http://dx.doi.org/10.1002/(SICI)1097-0266(199804)19:4<293::AID-SMJ982>3.0.CO;2-M

Gulati, R., Nohria, N., \& Zaheer, A. (2000). Strategic networks. Strategic Management Journal, 21(3), 203-215. SMJ102>3.0.CO;2-K http://dx.doi.org/10.1002/(SICI)1097-0266(200003)21:3<203::AID-

Håkansson, H., Ford, D., Gadde, L., Snehota, I., \& Waluszewski, A. (2009). Business in networks. Chichester: Wiley.

Hernández-Mogollon, R., Cepeda-Carrión, G., Cegarra-Navarro, J. G., \& Leal-Millán, A. (2010). The role of cultural barriers in the relationship between open-mindedness and organizational innovation. Journal of Organizational Change Management, 23(4), 360-376. http://dx.doi.org/10.1108/09534811011055377

Homburg, C., Klarmann, M., Reimann, M., \& Schilke, O. (2012). What drives key informant accuracy? Journal of Marketing Research, 49(4), 594-608. http://dx.doi.org/10.1509/jmr.09.0174

Houghton, S. M., Smith, A. D., \& Hood, J. N. (2009). The influence of social capital on strategic choice: An examination of the effects of external and internal network relationships on strategic complexity. Journal of Business Research, 62(12), 1255-1261. http://dx.doi.org/10.1016/jbusres.2009.01.002

Hsieh, M.-H., \& Tsai, K.-H. (2007). Technological capability, social capital and the launch strategy for innovative products. Industrial Marketing Management, 36(4), 493-502. http://dx.doi.org/10.1016/j.indmarman.2006.01.002

Hung, K.-P., \& Chou, C. (2013). The impact of open innovation on firm performance: the moderating effects of internal R\&D and environmental turbulence. Technovation, 33(10/11), 368-380. http://dx.doi.org/10.1016/j.technovation.2013.06.006

Iacobucci, D., Saldanha, N., \& Deng, X. (2007). A meditation on mediation: evidence that structural equations models perform better than regressions. Journal of Consumer Psychology, 17(2), 139153. http://dx.doi.org/10.1016/S1057-7408(07)70020-7

Jiménez-Jimenez, D., Valle, R. S., \& Hernandez-Espallardo, M. (2008). Fostering innovation: the role of market orientation and organizational learning. European Journal of Innovation Management, 11(3), 389-412. http://dx.doi.org/10.1108/14601060810889026

Jöreskog, K. G., \& Sörbom, D. (1996). LISREL 8 user's reference guide. Chicago, IL: Scientific Software International.

Karim, S., \& Kaul, A. (2015). Structural recombination and innovation: unlocking intraorganizational knowledge synergy through structural change. Organization Science, 26(2), 439-455. http://dx.doi.org/10.1287/orsc.2014.0952 
Kim, Y. [Yangmin], \& Cannella, A. A., Jr. (2008). Social capital among corporate upper echelons and its impacts on executive promotion in Korea. Journal of World Business, 43(1), 85-96. http://dx.doi.org/10.1016/j.jwb.2007.10.009

Kim, Y. [Youngok], \& Lui, S. S. (2015). The impacts of external network and business group on innovation: Do the types of innovation matter? Journal of Business Research, 68(9), 1964-1973. http://dx.doi.org/10.1016/j.jbusres.2015.01.006

Kogut, B., \& Zander, U. (1992). Knowledge of the firm, combinative capabilities and the replication of technology. Organization Science, 3(3), 383-397. http://dx.doi.org/10.1287/orsc.3.3.383

Kostopoulos, K., Papalexandris, A., Papachroni, M., \& Ioannou, G. (2011). Absorptive capacity, innovation, and financial performance. Journal of Business Research, 64(12), 1335-1343. http://dx.doi.org/10.1016/j.jbusres.2010.12.005

Kropp, F., Lindsay, N. J., \& Shoham, A. (2006). Entrepreneurial, market, and learning orientations and international entrepreneurial business venture performance in South African firms. International Marketing Review, 23(5), 504-523. http://dx.doi.org/10.1108/02651330610703427

Larson, A. (1992). Network dyads in entrepreneurial settings: a study of the governance of exchange relationships. Administrative Science Quarterly, 37(1), 76-104. http://dx.doi.org/10.2307/2393534

Lei, D., Hitt, M. A., \& Bettis, R. A. (1996). Dynamic core competences through meta-learning and $\begin{array}{llll}\text { strategic context. Journal of } & \text { Management, 22(4), 549-569. }\end{array}$ http://dx.doi.org/10.1177/014920639602200402

Lei, D., Slocum, J. W. \& Pitts, R. A. (1999). Designing organizations for competitive advantage: the power of unlearning and learning. Organizational Dynamics, 27(3), 24-38. http://dx.doi.org/10.1016/S0090-2616(99)90019-0

Leonard-Barton, D. (1992). The factory as a learning laboratory. Sloan Management Review, 34(1), 2338.

Lesser, E. L. (2000). Leveraging social capital in organizations, in knowledge and social capital: foundations and applications. Boston, MA: Butterworth- Heinemann.

Li, S. X., \& Greenwood, R. (2004). The effect of within-industry diversification on firm performance: synergy creation, multi-market contact and market structuration. Strategic Management Journal, 25(12), 1131-1153. http://dx.doi.org/10.1002/smj.418

Lin, H.-E., McDonough, E. F., Lin, S.-J., \& Lin, C. Y.-Y. (2013). Managing the exploitation/exploration paradox: the role of a learning capability and innovation ambidexterity. Journal of Product Innovation Management, 30(2), 262-278. http://dx.doi.org/10.1111/j.1540-5885.2012.00998.x

Lynn, G., Reilly, R. R., \& Akgün, A. E. (2000). Knowledge management in new products team: practices and outcomes. IEEE Transactions on Engineering Management, 47(2), 221-231. http://dx.doi.org/10.1109/17.846789

Madhavan, R., \& Grover, R. (1998). From embedded knowledge to embodied knowledge: new product development as knowledge management. Journal of Marketing, 62(4), 1-12. http://dx.doi.org/10.2307/1252283

Melé, D., Debeljuh, P., \& Arruda, M. C. (2006). Corporate ethical policies in large corporations in Argentina, Brazil and Spain. Journal of Business Ethics, 63(1), 21-38. http://dx.doi.org/10.1007/s10551-005-7100-y 
Mitchell, R., Parker, V., \& Giles, M. (2012). Open-mindedness in diverse team performance: investigating a three-way interaction. The International Journal of Human Resource Management, 23(17), 3652-3672. http://dx.doi.org/10.1080/09585192.2012.654807

Moran, P. (2005). Structural vs. relational embeddedness: social capital and managerial performance. Strategic Management Journal, 26(12), 1129-1151. http://dx.doi.org/10.1002/smj.486

Nahapiet, J., \& Ghoshal, S. (1998). Social capital, intellectual capital, and the organizational advantage. The Academy of Management Review, 23(2), 242-266. doi: http://dx.doi.org/10.5465/AMR.1998.533225

Nohria, N., \& Eccles, R. G. (1992). Networks and organizations: structure, form and action. Boston, MA: Harvard University Press.

O'Connor, G. C. (2008). Major innovation as a dynamic capability: a systems approach. Journal of Product Innovation Management, 25(4), 313-330. http://dx.doi.org/10.1111/j.15405885.2008.00304.x

Osman-Gani, A. M., \& Rockstuhl, T. (2008). Antecedents and consequences of social network characteristics for expatriate adjustment and performance in overseas assignments: implications for HRD. Human Resource Development Review, 7(1), 32-57. http://dx.doi.org/10.1177/1534484307312182

Peng, M. W., Wang, D. Y. L., \& Jang, Y. (2008). An institutional-based view of international business strategy: a focus on emerging markets. Journal of International Business Studies, 39(5), 920-936. http://dx.doi.org/10.1057/palgrave.jibs.8400377

Pérez-Luño, A., Cabello-Medina, C., Carmona-Lavado, A., \& Cuevas-Rodríguez, G. (2011). How social capital and knowledge affect innovation. Journal of Business Research, 64(12), 1369-1376. http://dx.doi.org/10.1016/j.jbusres.2011.01.014

Pittaway, L., Robertson, M., Munir, K., Denyer, D., \& Neely, A. (2004). Networking and innovation: a systematic review of the evidence. International Journal of Management Reviews, 5/6(3/4), 137168. https://dx.doi.org/10.1111/j.1460-8545.2004.00101.x

Podolny, J. M., \& Page, K. L. (1998). Network forms of organization. Annual Review of Sociology, 24, 57-76. http://dx.doi.org/10.1146/annurev.soc.24.1.57

Podsakoff, P. M., MacKenzie, S. B., Lee, J.-Y., \& Podsakoff, N. P. (2003). Common method biases in behavioral research: a critical review of the literature and recommended remedies. Journal of Applied Psychology, 88(5), 879-903. https://dx.doi.org/10.1037/0021-9010.88.5.879

Powell, W. W. (1990). Neither market nor hierarchy: network forms of organization. IN B. M. Staw \& L. L. Cummints (Eds.), Research in organizational behavior (pp. 295-336). Greenwich, CT: JAI Press.

Powell, W. W., \& Brantley, P. (1992). Competitive cooperation in biotechnology: learning through networks? In N. Nohria \& R. G. Eccles (Eds.), Networks and organizations: structure, form and action (pp. 366-394). Boston: HBS Press.

Powell, W. W., Koput, K. W., \& Smith-Doerr, L. (1996). Interorganizational collaboration and the locus of innovation: networks of learning in biotechnology. Administrative Science Quarterly, 41(1), 116-145. https://dx.doi.org/10.2307/2393988

Rhee, J., Park, T., \& Lee, D. H. (2010). Drivers of innovativeness and performance for innovative SMEs in South Korea: mediation of learning orientation. Technovation, 30(1), 65-75. http://dx.doi.org/10.1016/j.technovation.2009.04.008 
Ritala, P., \& Sainio, L. M. (2014). Coopetition for radical innovation: technology, market and businessmodel perspectives. Technology Analysis \& Strategic Management, 26(2), 155-169. http://dx.doi.org/10.1080/09537325.2013.850476

Rubera, G., \& Kirca, A. H. (2012). Firm innovativeness and its performance outcomes: a meta-analytic review and theoretical integration. Journal of Marketing, 76(3), 130-147. http://dx.doi.org/10.1509/jm.10.0494

Sadovnikova, A., Pujari, A., \& Mikhailitchenko, A. (2016). Radical innovation in strategic partnerships: a framework for analysis. Journal of Business Research, 69(5), 1829-1833. http://dx.doi.org/10.1016/j.jbusres.2015.10.064

Sampaio, C. H., Simões, C., Perin, M. G., \& Almeida, A. (2011). Marketing metrics: insights from Brazilian managers. Industrial Marketing Management, 40(1), 8-16. http://doi.org/10.1016/j.indmarman.2010.09.005

Sanchez-Casado, N., Cegarra Navarro, J. G., Wensley, A., Tomaseti-Solano, E. (2016). Social networking sites as a learning tool. The Learning Organization, 23(1), 23-42. http://dx.doi.org/10.1108/TLO-10-2014-0058

Sheng, M. L., \& Chien, I. (2016). Rethinking organizational learning orientation on radical and incremental innovation in high-tech firms. Journal of Business Research, 69(6), 2302-2308. http://dx.doi.org/10.1016/j.jbusres.2015.12.046

Sherman, J. D., Berkowitz, D., \& Souder, W. E. (2005). New product development performance and the interaction of cross-functional integration and knowledge management. The Journal of Product Innovation Management, 22(5), 399-411. http://dx.doi.org/10.1111/j.1540-5885.2005.00137.x

Sheth, J. N. (2011). Impact of emerging markets on marketing: rethinking existing perspectives and practices. Journal of Marketing, 75(4), 166-182. http://dx.doi.org/10.1509/jmkg.75.4.166

Sinkula, J. M. (2002). Market-based success, organizational routines, and unlearning. Journal of Business \& Industrial Marketing, 17(4), 253-269. http://dx.doi.org/10.1108/08858620210431660

Sinkula, J. M., Baker, W. E., \& Noordewier, T. (1997). A framework for market-based organizational learning: Linking values, knowledge and behaviour. Journal of the Academy of Marketing Science, 25(4), 305-318. http://dx.doi.org/10.1177/0092070397254003

Slater, S. F., Mohr, J. J., \& Sengupta, S. (2014). Radical product innovation capability: literature review, synthesis, and illustrative research propositions. Journal of Product Innovation Management, 31(3), 552-566. http://dx.doi.org/10.1111/jpim.12113

Song, M., Droge, C., Hanvanich, S., \& Calantone, R. J. (2005). Marketing and technology resource complementarity: an analysis of their interaction effect in two environmental contexts. Strategic Management Journal, 26(3), 259-276. http://dx.doi.org/10.1002/smj.450

Sorescu, A. B., Chandy, R. K., \& Prabhu, J. C. (2003). Sources and financial consequences of radical innovation: insights from pharmaceuticals. Journal of Marketing, 67(4), 82-102. http://dx.doi.org/10.1509/jmkg.67.4.82.18687

Sousa, C. M. P., \& Lengler, J. (2009). Psychic distance, marketing strategy and performance in export ventures of Brazilian firms. Journal of Marketing Management, 25(5/6), 591-610. http://dx.doi.org/10.1362/026725709X461876

Stam, W., Arzlanian, S., \& Elfring, T. (2014). Social capital of entrepreneurs and small firm performance: a meta-analysis of contextual and methodological moderators. Journal of Business Venturing, 29(1), 152-173. http://dx.doi.org/10.1016/j.jbusvent.2013.01.002 
Story, V., Daniels, K., Zolkiewski, J., \& Dainty, A. R. J. (2014). The barriers and consequences of radical innovations: introduction to the issue. Industrial Marketing Management, 43(8), 12711277. http://dx.doi.org/10.1016/j.indmarman.2014.09.001

Story, V., O'Malley, L., \& Hart, S. (2011). Roles, role performance, and radical innovation competences. Industrial Marketing Management, 40(6), 952-66. http://dx.doi.org/10.1016/j.indmarman.2011.06.025

Subramaniam, M., \& Youndt, M. A. (2005). The influence of intellectual capital on the types of innovative capabilities. Academy of Management Journal, 48(3), 450-463. http://dx.doi.org/10.5465/AMJ.2005.17407911

Suseno, Y., \& Ratten, V. (2007). A theoretical framework of alliance performance: the role of trust, social capital and knowledge development. Journal of Management and Organization, 13(1), 423. http://dx.doi.org/10.1017/S1833367200003874.

Tellis, G. F., Prabhu, J. C., \& Chandy, R. K. (2009). Radical innovation across nations: the preeminence of corporate culture. Journal of Marketing, 73(1), 3-23. http://dx.doi.org/10.1509/jmkg.73.1.3

Tjosvold, D., \& Poon, M. (1998). Dealing with scarce resources: open-minded interaction for resolving budget conflicts. Group \& Organization Management, 23(3), 237-255. http://dx.doi.org/10.1177/1059601198233003

Wang, G., Dou, W., Zhu, W., \& Zhou, N. (2015). The effects of firm capabilities on external collaboration and performance: the moderating role of market turbulence. Journal of Business Research, 68(9), 1928-1936. http://dx.doi.org/10.1016/j.jbusres.2015.01.002

Wang, M.-C., \& Fang, S.-C. (2012). The moderating effect of environmental uncertainty on the relationship between network structures and the innovative performance of a new venture. Journal of Business \& Industrial Marketing, 27(4), 311-323. http://dx.doi.org/10.1108/08858621211221689

Weiss, A. M., \& Heide, J. B. (1993). The nature of organizational search in high technology markets. Journal of Marketing Research, 30(2), 220-233. http://dx.doi.org/10.2307/3172829

Wernerfelt, B. (1984). A resource-based view of the firm. Strategic Management Journal, 5(2), 171180. http://dx.doi.org/10.1002/smj.4250050207

Woodside, A. G., \& Biemans, W. G. (2005). Modeling innovation, manufacturing, diffusion and adoption/rejection processes. Journal of Business \& Industrial Marketing, 20(7), 380-393. http://dx.doi.org/10.1108/08858620510628614

Wu, W.-Y., Chang, M.-L., \& Chen, C.-W. (2008). Promoting innovation through the accumulation of intellectual capital, social capital, and entrepreneurial orientation. $R \& D$ Management, 38(3), 265277. http://dx.doi.org/10.1111/1467-9914.00120-i1

Xin, J. Y., Yeung, A. C. L., \& Cheng, T. C. E. (2009). Radical innovations in new product development and their financial performance implications: an event study of US manufacturing firms. Operations Management Research, 1(2), 119-128. http://dx.doi.org/10.1007/s12063-009-0017-3

Yang, J., Alejandro, T. G. B., \& Boles, J. S. (2011). The role of social capital and knowledge transfer in selling center performance. Journal of Business \& Industrial Marketing, 26(3), 152-161. http://dx.doi.org/10.1108/08858621111115877

Zeng, S. X., Xie, X. M., \& Tam, C. M. (2010). Relationship between cooperation networks and innovation performance of SMEs. Technovation, 30(3), 181-194. http://dx.doi.org/10.1016/j.technovation.2009.08.003 


\section{Authors' Profiles}

Marcelo Gattermann Perin

Av. Ipiranga, 6681, 90619-900, Porto Alegre, RS, Brazil. E-mail address: mperin@pucrs.br

Cláudio Hoffmann Sampaio

Av. Ipiranga, 6681, Prédio 50, 90619-900, Porto Alegre, RS, Brazil. E-mail address: csampaio@pucrs.br

Daniel Jiménez-Jiménez

Universidad de Murcia, Dpto. Organización de Empresas y Finanzas, Campus de Espinardo, 30100, Murcia, Spain. E-mail address: danieljj@um.es

Juan Garcia Cegarra-Navarro

Facultad de Ciencias de la Empresa, Calle Real 3, Cartagena, 30201, Murcia, Spain. E-mail address: juan.cegarra@upct.es 